\title{
For the Sake of Faith of for the Sake of Land? Religion as a Factor of Conflicts between Migrants and Old-Dwellers in the Course of the Great Siberian Migration (Evidence from the Ognevo Village, Biysk District)
}

\author{
Alexey K. Kirillov ${ }^{\mathrm{a}}$ and Anastasiya G. Karavayeva ${ }^{\mathrm{b} *}$ \\ ${ }^{a}$ Institute of History SB RAS \\ 8 Nikolaeva Str., Novosibirsk, Russia, 630090, Russia \\ ${ }^{b}$ State Archive of the Tomsk Region \\ 78 Vodyanaya Str., Tomsk, 634009, Russia
}

Received 01.06.2018, received in revised form 04.09.2018, accepted 10.09.2018

The article draws reader's attention to the peasant migration from European Russia to Siberia between the abolition of serfdom at Russia (1861) and World War I (1914). This phenomenon is well known as an example of successful migration that gave a powerful impetus to the development of Siberia. But the issue of the reasons that prevented this process from becoming as influential as the massive transatlantic resettlement of Europeans in the second half of the 19th and the beginning of the 20th century has not been sufficiently studied yet. In search of the answer the authors take for consideration conflicts between Siberian old dwellers and newcomers. In historiography one of the reasons for the clashes between them is considered to be the religious contradictions between the supporters of the official Orthodoxy (those who came from European Russia) and the Old Believers popular among the old dwellers. The authors take the village of Ognevo (Altai) as a subject for a case study. This case is covered comprehensively by documents coming from both the migrants and the old dwellers as well as from the state officials who had to face the peasants' complaints. The authors conclude that religion was just an excuse for conflicts. The real cause of the conflict is the lack of land, which became a scarce resource for the first time in Siberia right in the period of the Great Siberian migration.

Keywords: Migration, Post-reform Russia, Stolypin's migration, Old-Believers of Altai, Migration drivers.

Research area: history.

Citation: Kirillov, A.K., Karavayeva, A.G. (2018). For the sake of faith of for the sake of land? Religion as a factor of conflicts between migrants and old dwellers in the course of the Great Siberian migration (evidence from the Ognevo village, Biysk district). J. Sib. Fed. Univ. Humanit. soc. sci., 11(9), 1399-1411. DOI: 10.17516/1997-1370-0312. 


\section{Introduction}

The second half of the $19^{\text {th }}$ century is the beginning of the mass resettlement of peasants to Siberia, which reached its peak during Stolypin's period. More than half a century ago an American author D. Treadgold called this phenomenon the Great Siberian migration (Treadgold, 1957). And indeed: it sharply increased the population of Siberia and gave a push to a new stage in the region's life, first of all - Tomsk Province, where most peasants settled.

The paradox is that the Great Siberian migration has not become the Great Russian resettlement comparable to the movement of Europeans across the ocean in precisely the same decades. The second half of the $19^{\text {th }}$ century in general brought a revival of migration flows between different parts of the world (McKeown, 2004). The most studied part of these flows concerns resettlement across the Atlantic that, to different extents, affected most of the countries of Europe (Hatton, Williamson, 1998). The brightest example of the European resettlement in the United States is Sweden with its agrarian overpopulation: from 1864 to 1908 about one million people left the country, so by the end of this period every fifth Swede lived in the United States! (Teterevleva, 2012) To reach the same figures, not three but thirty million people should have left European Russia in the Stolypin years (the time of the upswing of the resettlement wave).

For Sweden, such resettlement meant a crisis: young Swedes left for another country, deprived their homeland of their productive forces. The Swedish government was beating the alarm and developing a system of benefits for those who stayed in the country. For Russia, such resettlement could be a boon. One stone would have killed two birds: the acute problem of land shortage in the centre of the country would have been removed and the great spaces of Asian Russia would have been settled and, thereby, recognized as the Russian possession. W. Sunderland rightly emphasizes the difference between the two Russian concepts that the officials used to describe the movement of population to Siberia a hundred years ago: "resettlement" places the centre of gravity on the movement of peasants beyond the Urals, "colonization" means the development of Asian Russia (Sunderland, 2000). In Russian life, these concepts were intertwined, and the Resettlement Department discussed the critical questions of positioning its case in the periodic collection "Questions of colonization."

Since the late 1880's, the Russian government has been developing a system of benefits for immigrants. In the 1890's it built a railway across Siberia - but even in 1907-1910 the figures for resettlement from European Russia through the Urals are 
comparable only with the natural increase in population in the same period (Tiukavkin, 2001). Why did not the Russian resettlement reach the Swedish level? Economists, who have considered massive transatlantic resettlement with the help of mathematical methods, speak about the essential role of the gap in the level of wages as a reason forcing young people to leave their native lands (Hatton, Williamson, 1994). Clearly, this is not about the Siberian case: peasants went to Siberia not to be employed in factories, but, on the contrary, in order to preserve the usual peasant way of life. However, the very formulation of the question within the framework of the "push-pull model" that is popular among the researchers of migration is useful. The application of this model to mass Swedish resettlement led to the conclusion that in the beginning the expellant factors were more important (overpopulation in places to be left), and gradually the priority shifted to the attracting factors (favourable conditions in places of settling) (Norström, 1988). Speaking of Russia at the end of the $19^{\text {th }}$ and the beginning of the $20^{\text {th }}$ century, one should think not only about the forces of expulsion (which for a long time, albeit not forever, have been weakened by the attachment of peasants to allotment due to redemption payments), but also about the forces of attraction.

Siberia itself, with its beckoning spaciousness, paradoxically, did not provide many opportunities for settlement of the new comers. There was no developed industry, no big cities: inevitably, the main method for settling of the immigrants was to build a peasant farm. To build a farm in an open field was too difficult a task: at first, it was necessary to settle in with the old dwellers, to work for them. Simultaneously, they bought a house, equipped the farmstead, and it seemed that it was possible to start its own arable land. Here is a contradiction: the settlers thought that the Siberian 15 dessiatines were the land abundance where there is enough space for everyone; the old dwellers perceived the same land as barely sufficient and drove the settlers away. It turned out that Siberia was vast, but there was nowhere to move. In the early 1880 's, when the scale of resettlement was still much (a hundred times!) less than in the Stolypin's period, the contradictions between the migrants and the old dwellers had already resulted in a series of clashes that brought Russian readers' attention to the south of Tomsk Province.

The very fact of the existence of contradictions between the old dwellers and migrants has long been known to historians. In the most detailed contemporary work on resettlement, the enumeration of some examples of this kind is summarized by the conclusion that "the population of the region was a complex polyethnic and polyconfessional conglomerate" (Razgon, Khramkov, Pozharskaia, 2010: 159). Thus, 
conflicts are simply an inevitable stage of adaptation of newcomers to an unfamiliar environment.

An essential role in such understanding of conflicts is played by the contradictions between the Old Believers' traditions of Altai and the official Orthodoxy of the migrants. In the middle of the $19^{\text {th }}$ century, Tomsk Province was one of the most "oldrite" provinces in Russia. Despite the lack of reliable statistics of the "fringe group", local priests and church authorities knew very well that whole villages that consist entirely of Old Believers are a common thing in Altai. Altai, therefore, became one of the places of active application of the military-police force during the aggravation of the struggle for "Orthodoxy, autocracy, nationality" under Nicholas I's rule (Pokrovskii and Zol'nikova, 2002). Secret hermitages were destroyed, old books were suppressed, and peasants were forced to accept, if not official Orthodoxy, at least one religion. And even the law of May 3, 1883' that eased the situation of the Old Believers in general, did not bring the desired relief. It was in Tomsk Province, where the leaders of the Old Believers were perceived by the official church as an influential competitor, that the church authorities strengthened the struggle for the congregate after the reform of 1883. One of the bishops of Old Believers "compared victimization of the Tomsk Old Believers by the authorities at the turn of the 1880's-1890's with "the Nicolaevsky" victimization in the second quarter of the $19^{\text {th }}$ century" (Starukhin, 2015: 65). K.Iu. Ivanov, in his dissertation specifically devoted to the South of Western Siberia, notes that in the 1860's and the 1870's the spiritual authorities sometimes even resorted to the help of the Tomsk governor to "influence" the Old Believers; "later the role of the secular power gradually weakened" (Ivanov, 2001: 22).

That is why historians easily find direct indications of conflicts between olddwellers and migrants that are connected with religious differences in documents issued by peasants and in the essays of outside observers (Razgon, Khramkov, Pozharskaia, 2010: 150; Lipinskaia, 1996: 78-79). However, the question of the extent to which religious differences were the cause of the conflicts remains unanswered.

For the $18^{\text {th }}$ century with its mass Old-Believers' "burnings" (self-immolation), historians have learned to separate the form of struggle from its essence. The notions of "anti-feudal protest" and "class struggle" remained in the past, but the main thing remained in the treasury of historical science: the conclusion that the intensity of the struggle was determined by the degree of material (administrative, fiscal) pressure of

Complete collection of laws of the Russian Empire. $3^{\text {rd }}$ collection, 3, 219-221. No. 1545. On granting some of the civil rights to dissenters and teaching spiritual disciplines. 
the state. The second half of the $19^{\text {th }}$ century was the time when the role of religion in the life of Russian society was declining. Was the religious factor really creating clashes during the peasant resettlement?

\section{Methods}

It is this story that we can analyse in more detail based on the materials of a special case from the fund of the Tomsk provincial administration'. The sketchy information about the clashes between the old-dwellers and the migrants is plentiful, but fragmentary: as a rule, it represents only one point of view on the case, without details. Special cases, each of which represents an individual case in its entirety (peasants' view, old-dwellers' view expressed in different documents; opinions of different officials, often contradictory), allow us to conduct a thorough analysis of the case (case study, a favourite term used by economists). This approach is valuable because it allows you to see the hidden meanings and subtexts that are not directly formulated, but are derived from the comprehension of each document taking into account the entirety. In the fund of the Tomsk provincial administration, there were not many such cases left; one of them is studied in this article. It will help us to assess the degree of influence of the religious factor in the occurrence of conflicts between migrants and old-dwellers.

\section{Main part}

First of all, it is worthwhile to briefly outline the basis of this matter. History began in 1891 - the time of a catastrophic harvest failure that caused the famous famine in European Russia. One way to get away from the famine - although difficult and risky - was to flee to Siberia, to the Altai lands. That was what the group of 24 families of peasants from the Voronezh Governorate did. In the early spring of 1892 they found themselves in the village of Ognevo in the Nizhne-Charyshskaya volost of the Biysk District. There were over 30 dessiatines of land per male - even by the standards of the generous Siberian land management this was a double norm. The media covered the famine catastrophe of 1891/92 very vividly: it was not a local incident, but an allRussian disaster. The Tomsk governor contributed to the aid of the hungry: he ordered the old-dwellers in Tomsk not to send away the new settlers.

State Archives of Tomsk Region. F. F-3. Op. 44. D. 382. 
At first, it seemed that the peasants gained mutual understanding. In any case, the migrants spent their money in the total amount of about 2000 roubles on buying houses from the Ognevo old-dwellers. But when they tried to acquire their own economy, the old-dwellers harshly opposed. Having filed a complaint to the governor, the olddwellers received a response in their favour even before the beginning of the arable season of 1893. Why the governor did not support the migrants, whom he himself had recently helped, could be easily understood: he acted within the law. The governor could oblige the old-dwellers, in the form of an exceptional measure, to allow the migrants to reside. But he had no right to demand that the migrants be given arable land. The use of land is a privilege for a member of the peasant society (community). Those who did not receive an order of reception from the assembly could not demand land. That was one of the foundations of the peasant life. The governor suggested that the settlers either obtained an order of reception or went to other places on vacant land.

Thus, at the beginning of 1893 the government designated the line it pursued throughout the confrontation. This line is not as straightforward as it may seem. Senior officials of the governorate government regularly reminded the migrants that the power of law was on the side of the old-dwellers, and it was necessary to look for some legal solution. But they did not use the rough police force to immediately expel the foreigners, as the old-dwellers would have liked. The officials clearly looked at their tasks more widely than just adherence to the letter of the law. Somewhat roughening the situation, we can say that the authorities were dragging their feet in the hope that the peasants would somehow settle the matter themselves.

And indeed, the peasants played a key role in the further development of events. Migrant, having familiarized themselves with the governor's first response, sent a counterclaim where they painted their situation in gloomy colours and asked not to be expelled from Ognevo. The reciprocal attempt of the governor to settle the matter by peace allowed migrants to hold on to their occupied positions until summer and to carry out sowing. Given the unwritten rule of peasant life - as a man sows, so shall he reap - that meant that they stayed at least until the fall. Moreover, another ten migrants came to Ognevo. This caused two complaints in a row (in May and June) from the olddwellers to the governor with demands to send away the foreigners. Meanwhile, one of the "new migrants", Vasilii Iaprintsev, sent his complaint against the old-dwellers to the Tsar. Of course, the Tsar did not read this paper; it was sent back as usual. The case was replenished with materials to investigate Iaprintsev's complaint, but the policy of local authorities did not change. 
Meanwhile, the old-dwellers were convinced of the uselessness of complaints and turned to the use of force. In 1893, they still tried to harm surreptitiously: to frighten someone privately (by word or fist), or to break a fence and spoil yard. The next year, more decisive actions followed. In early May 1894, when the migrants tried to plough again, the old-dwellers took away two dozen ploughs from them. The migrants, however, did not leave the village - despite losing a part of tools, they managed to conduct ploughing and sowing. In response, on June 14, 1894, the old-dwellers staged a real havoc, having broken eight resettlement estates and beaten the owners.

The migrants still refused to leave, and a year later the old-dwellers once again got physical. In the list of those who suffered from the havoc on June 26, 1895, there were 38 migrants. Despite the larger scale compared to June 1894, it seems that the confrontation evolved from an attempt to send out the new settlers into an attempt to revenge them for staying. In any case, we are no longer talking about weaning ploughs, and the damage with rare exceptions is limited to the removal of relatively inexpensive items, such as hammers, ropes, axes, etc. Hence, the migrants, although beaten, had the opportunity to plough, and therefore preserved the opportunity to stay in the village.

The migrants managed to survive: in the first months of 1896 the old-dwellers could neither drive them out of their village, nor deprive them of farming. And in the spring the situation changed dramatically. The law of April 27, $1896^{1}$ settled all the disputes between migrants and old-dwellers in Altai in favour of such people as G.F. Byrylov. "Those who had houses" and "those who were engaged in arable farming" were ordered to be attached to old-dwellers' communities, regardless of the desire of the old-dwellers, provided only that the land is sufficient for a 15-dessiatine allotment. So it happened: from 1893 to 1899, the population of Ognevo had grown three times, the allotment fell to 13.5 dessiatines $^{2}$. It is clear that the lion's share of the new villagers was provided not by the natural growth, but by the enumeration of migrants. The settlers had won thanks to their own persistence and not without the help of the authorities that wanted to increase the density of the Siberian population.

Each action in this story that lasted more than three years was supported by several documents. Thanks to this, we have several descriptions of the case from the old-dwellers (different ones), several descriptions from the migrants (also different)

Complete collection of laws of the Russian Empire. $3^{\text {rd }}$ collection. 16 (1), 323-324. No. 12837. "On settlement of migrants of Altai District, Departments of His Majesty's Cabinet."

2 The list of inhabited places of Tomsk province for 1893 (1983). Tomsk: Typography of the provincial government, pp. 174-175; The list of inhabited places of Tomsk province for 1899 (1899). Tomsk: Partnership "Pechatnia of S.P. Iakovlev" (Provincial Printing House), pp. 650-651 
and from peasant officials (two were involved in the case); there are decisions of two successive governors. It is a rich collection to study the views of various people about the causes of what was happening.

The religious argument that interests us most of all has been put forward by the migrants. Already in the first petition they pointed out the existence of the causeand-effect linkage between the decision of the migrants to build a church and the desire of the old-dwellers (mostly the Old Believers) to deport the migrants. Time after time the new villagers insistently emphasized their own faithfulness as opposed to the ideological irregularity of the old residents. However, it is not clear what follows from this: either the fact that the religious factor really played a certain role or the fact that the migrants pragmatically used the official ideology for their own purposes.

The appeals of migrants are more interesting for us, because the material aspect of the matter is consistently exposed. The settlers spent a lot of money on buying houses from the old-dwellers (and this information was thoroughly confirmed by figures from the old residents themselves), and then they wrote, "we cannot possibly move to one of the distant sites, since we and our principals shall perish on the road without money1."

In most of their complaints, the old-dwellers themselves do not touch the religious side of the matter putting forward two key considerations. First of all, they rely on a law that piously protects their right not to give orders of reception in the absence of desire. But not limited to the formal side, they also give reasons in essence. For the olddwellers, the essence is in the artificially (with the help of ponds) irrigated floodable hayfields, which the settlers pretend to occupy for arable land. The last argument is important for us, because it explains why with seemingly abundant allotment (34 dessiatines per capita), the old residents do not have a free land: after all, pastures absorb more than arable land.

The non-disclosure about church affairs is logical for the old-dwellers: here they take a weak position. But they mention this in one document: this is an "explanation" compiled by a volost assessor, in which complaints of settlers on harassment from old residents are accompanied by comments of the old residents themselves. In particular, the statement of the Orthodox on the refusal of the Old Believers to build an Orthodox Church contrasted with the assertion that "there were no more obstacles from the olddwellers to the construction of the church", and "only about 200 tree trunks were harvested for the construction of the church, and it was not 600 trees that were stored by

State Archives of Tomsk Region. F. F-3. Op. 44. D. 382. L. 14. 
the old-dwellers, but not harvested '." The old-dwellers tend to understate the successes of unpleasant construction, and thus recognize the existence of a fact of construction. However, this does not give us grounds to judge the significance of religious differences in the emergence of a conflict between the old-dwellers and migrants.

Simultaneously (incidentally, but with no doubt), both sides recognize the fact that supporters of official Orthodoxy are in the village regardless of the migrants, and even before the arrival of the latter the old-dwellers, the followers of Nikon, decided to build a church. It was this fact that the official of the $2^{\text {nd }}$ section of Biysk District emphasized in order to turn it against the migrants (the migrants ineffectively bring in the church questions to their conflict with the old-dwellers). However, his opinion is clearly prejudiced. Throughout his review, the official is clearly trying to blame the settlers. Even the recorded fall of the pregnant migrant caused by a push of the olddweller is not outrageous to him ("Zazdravnye's peasant was not brutally beaten, but only Plyasovskie's peasant pushed her into the chest ${ }^{2}$ )." On the other hand, the official of the $1^{\text {st }}$ section of the same district (in which Ognevo was at the time of the beginning of this whole story) agreed that the main cause of the conflict was religious, and it was necessary to support the migrants. However, his position was discredited by the fact that, in another opinion submitted on the same day, he supported the old-dwellers' point of view and proposed a solution in their favour (thereby exposing his insincerity).

The provincial leadership (both the governors and the provincial government) looks the least biased in this whole story: as already mentioned the highest officials adhered to the policy of the greatest detachment from the conflict. It is not indifference: trying to keep the status quo in Ognevo, senior officials at the same time discussed the prospects for changing legislation. And of course, the law of April 27, 1896, which allowed the settlers to win an unconditional victory, was drawn up with the participation of the Siberian authorities. At the same time, in the exchanges of views between the governor and the government authorities and in directives from Tomsk to lower-level officials, the religious theme was never mentioned, everything was about the land (availability or absence of surplus, possibility or impossibility of settling) and about the stage of cooperation between old-dwellers and migrants (if the old-dwellers sold houses, then it was their fault). The provincial officials did not play a religious card, which the settlers persistently tried to shove.

State Archives of Tomsk Region. F. F-3. Op. 44. D. 382. L. 35-36.

Idid. L. 41. 
An independent argument when deciding the importance of the Old Believers' problem is the development of the situation. In 1892, it all began with the demands and complaints of old-dwellers, which were easily stopped by the governor's decision to maintain the status quo. In the following years, the fever pitch is much higher: it comes to havocs. And just at this time the number of migrants is increasing; they come even from neighbouring villages (where they lived the first years of their Siberian life). They arrive with their own houses, and not with those bought at the site, which is specially noted in the petition of the old-dwellers (it means that the old-dwellers stopped selling - and this is also an indicator). At the same time, nothing is said about the change in the situation with the church.

\section{Conclusion}

All the above facts and considerations lead to a certain conclusion. Neither officials, nor, most importantly, peasants attached decisive importance to the religious factor. It was not the main thing for migrants who were mostly concerned with money and forces already invested in the new place. Nor was it the main thing for old-dwellers, most of whom had already become accustomed to the presence of adherents of official Orthodoxy in the community. Whether this religious duality of the Ognevo settlement was primordial, or it arose in recent times, in any case, the followers of Nikon were full-fledged members of the peasant society, and nobody organized havocs for them building the church. The irritation of the old-dwellers, the degree of destructiveness of their methods of struggle grew in direct proportion to the exhaustion of those lands that provided wealth to the most influential of them.

No matter how much the Siberian Kerzhaks valued their special faith - a symbol of independence, they were ready to exercise religious tolerance in practical communication with their neighbours. The role of the religious motive in the clashes of old-dwellers with migrants did not go beyond the excuse for outbreaks. The combustible material was the deficit of land as the basis for peasant farming. The beginning of the great resettlement meant the end for the Siberian land freemen, a new stage in the life of Siberia, and above all - Altai that was the main place for the Great Siberian resettlement. The questions of religion turned out to be of secondary importance in comparison with the issues of exploring the open spaces. Old Believers' Altai has turned into migrant Altai.

Conflicts between the migrants and the old-dwellers, even in the case of religious colouring, were caused by a radical phenomenon: the transformation of arable land 
available for use into a scarce resource. It is this circumstance that, even before the construction of the Trans-Siberian railway, put a limit that did not allow the Great Siberian migration to turn into the Great Russian migration.

\section{References}

Hatton, T., Williamson, J. (1994). What Drove the Mass Migrations from Europe in the Late Nineteenth Century? In Population and Development Review, 20 (3) (Sep., 1994), 533-559. DOI: $10.2307 / 2137600$

Hatton, T., Williamson, J. (1998). The Age of Mass Migration: Causes and Economic Impact. Oxford University Press, 301 p.

Ivanov, K.Iu. (2001). Staroobriadchestvo Iugo-Zapadnoi Sibiri Vtoroi Poloviny $X I X$ - nachala XX vv. [Old Believers of the South-West Siberia at the Second half of 19 th - beginning of the $20^{\text {th }}$ century]. Avtoref. dis. ... kand. ist. nauk [PhD theses]. Kemerovo, 30 p.

Lipinskaia, V.A. (1996). Starozhily i pereselentsy. Russkie na Altae, XVIII Nachalo XX Veka [Old dwellers and newcomers. Russians in Altai, $18^{\text {th }}$ century beginning of the $20^{\text {th }}$ century]. Moscow, Nauka, $269 \mathrm{p}$.

McKeown, A. (2004). Global Migration, 1846-1940. In Journal of World History. 15 (2) (Jun., 2004), 155-189.

Norström, T. (1988). Swedish Emigration to the United States Reconsidered. In European Sociological Review, 4 (3) (Dec., 1988), 223-231.

Pokrovskii, N.N., Zol'nikova, N.D. (2002). Starovery-Chasovennye Na Vostoke Rossii v XVIII-XX vv.: Problemy Tvorchestva $i$ Obshchestvennogo Soznaniia. ["Dissentient" Old-Believers at the East of Russia in the $18^{\text {th }}-20^{\text {th }}$ centuries: Their Works and Social Conscience]. Moscow, Pamiatniki istoricheskoi mysli, 471 p.

Razgon, V.N., Khramkov, A.A., Pozharskaia, K.A. (2010). Stolyipinskaia Agrarnaia Reforma i Altai. [Stolypin's agrarian reform and Altai]. Barnaul, Izdatelstvo Altaiskogo universiteta, $278 \mathrm{p}$.

Starukhin, N.A. (2015). Sibirskie Obshchestva Belokrinitskikh Staroverov vo Vtoroi Polovine XIX - Nachale XXv. [Siberian Communes of the Belaya Krinitsa Old Believers in the Second Half of the $19^{\text {th }}$ - Beginning of the $20^{\text {th }}$ Century]. Novosibirsk, Institut istorii SO RAN, 206 p.

Sunderland, W. (2000). The "Colonization Question": Visions of Colonization in Late Imperial Russia. In Jahrbücher für Geschichte Osteuropas. Neue Folge, Bd. 48, H. 2, 210-232. 
Teterevleva, T.P. (2012). Transatlanticheskaia Emigratsiia v Shvedskoi Istoriografii XX Veka: Osnovnye Podkhody i Problemy Izucheniia [Transatlantic Emigration as Seen by the Swedish Historiography: Main Issues and Approaches]. In Skandinavskie chteniia 2010 goda: etnograficheskie i kul'turno-istoricheskie aspekty [Scandinavian Readings 2010: aspects of ethnography and cultural history]. Saint-Petersburg, 246-258. Available at: http://www.kunstkamera.ru/files/lib/987-5-88431-196-1/987-588431-196-1_14.pdf

Tiukavkin, V.G. (2001). Velikorusskoe Krest'ianstvo i Stolypinskaia Agrarnaia Reforma [Russian Peasantry and Stolypin's Agrarian Reform]. Moscow, 304 p.

Treadgold, D. (1957). The Great Siberian Migration: Government and Peasant in Resettlement from Emancipation to the First World War. Princeton: Princeton university press (Second edition: 2015). 278 p.

\title{
За веру или за землю? Религия как фактор старожильческо-переселенческих конфликтов \\ В ходе Великого сибирского переселения (на материалах с. Огнево Бийского округа)
}

\author{
А.К. Кириллов ${ }^{\mathrm{a}}$ А.Г. Караваева ${ }^{\sigma}$

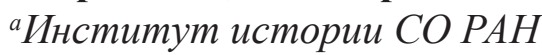 \\ Россия, 630090, Новосибирск, ул. Академика Николаева, 8 \\ ${ }^{б}$ Государственныий архив Томской области \\ Россия, 634009, Томск, ул. Водяная, 78
}

\begin{abstract}
Статья обращает внимание читателя на переселение крестьян из Европейской России в Сибирь между отменой крепостного права в России (1861) и Первой мировой войной (1914). Это явление хорошо изучено как пример успешного переселения, давшего мощңный толчок развитию Сибири. Но недостаточно изучен вопрос о причинах, не позволивших этому прочессу стать столь же влиятельным, как массовое трансатлантическое переселение европейцев во второй половине XIX - начале XX в. B поисках ответа на этот вопрос авторы обращают внимание на конфликты между сибирскими старожилами и переселенцами. Одной из причин столкновений между ними в историографии принято считать религиозные противоречия между сторонниками офищиального православия (приезжавшими из Европейской России) и старообрядиами, которых было много среди старожилов. Применяя метод отдельных случаев (сале study), авторы досконально изучают историю противоборства в алтайской деревне Огнево в 1890-е г2. Для этого используются документы, исходящие и от старожилов, и от переселенцев, и от чиновников, которым жаловались крестьяне. Авторы с уверенностью заключают, что религия выступает лишь поводом для столкновений.
\end{abstract}


Действительная же причина конфликта - нехватка земли, впервые в Сибири ставшей дефицитным ресурсом как раз в ходе Великого сибирского переселения.

Ключевые слова: миграции, пореформенная Россия, стольпинское переселение, старообрядиы Алтая, движущие силы переселения.

Научная специальность: 07.00.00-исторические науки. 